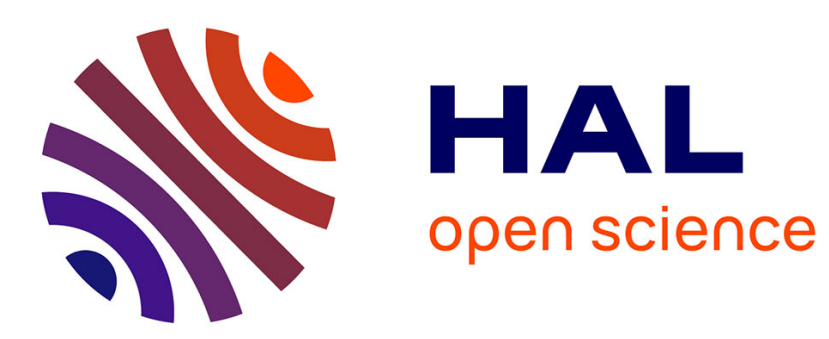

\title{
Doing ethnomusicological research as a white woman in Cameroon and the Central African Republic
}

\author{
Susanne Fürniss
}

\section{To cite this version:}

Susanne Fürniss. Doing ethnomusicological research as a white woman in Cameroon and the Central African Republic. Bonnie L. Hewlett. The Secret Lives of Anthropologists. Lessons from the Field, Routledge, pp.75 - 90, 2020, 978-1-138-50185-0. halshs-02403436

\section{HAL Id: halshs-02403436 \\ https://shs.hal.science/halshs-02403436}

Submitted on 10 Dec 2019

HAL is a multi-disciplinary open access archive for the deposit and dissemination of scientific research documents, whether they are published or not. The documents may come from teaching and research institutions in France or abroad, or from public or private research centers.
L'archive ouverte pluridisciplinaire HAL, est destinée au dépôt et à la diffusion de documents scientifiques de niveau recherche, publiés ou non, émanant des établissements d'enseignement et de recherche français ou étrangers, des laboratoires publics ou privés. 


\title{
DoIng Ethnomusicological ReSEARCH AS A White WOMAN IN CAMEROON AND THE CENTRAL AfRICAN REPUBLIC ${ }^{1}$
}

\author{
Susanne Fürniss
}

In this chapter, the author draws on her experiences as a woman researcher in the field and offers advice on how behavior might be appropriately adjusted in common field situations. She discusses respect and the establishment of clear boundaries between the researcher and the people with whom she works, with particular reference to gender discrimination, sexual harassment, and simply being fed up, financial solicitations, and authority, but also highlights the moments of true joy which may emerge from close collaboration with local musicians. The first part addresses issues of being a woman in the field, and how these changed or stayed the same of the course of her career. The second focuses more on negotiating local people's perception of the author's work as "a man's job".

\section{BEING A WOMAN IN THE FIELD}

For my first two trips to the Central African Republic (CAR), I was part of a research team consisting of three French men and myself. The men were my professor, one of his colleagues, and a Masters student who was younger than me. We travelled with two Land Rovers, because we had a lot of technical equipment and were accompanied by a Central African research assistant and a cook. Gender issues were present both within the team and in our interactions with local authorities and village people, but never with the Aka Pygmies we were working with. Later, when I was a scholar myself and working alone or with younger students under my charge, these issues also mainly occurred with people we were not directly working with.

\section{Married/unmarried and travelling alone}

It is crucial for us to introduce ourselves not only as scholars, but also as private persons. In many regions, people have very little personal experience with white [76] women. Their image of Western femininity is constructed with elements from two incompatible extremes: the women they may encounter in the region - mainly religious sisters - on one hand, and videos and magazines on the other. Needless to say, the latter do not provide a well-informed image of the values and the behaviors of an average Western university student. They present young women as singles, more oriented towards sex than the construction of stable unions and families. In order to position herself in between these extremes, it might be necessary for the young female student or scholar to let people know that she is already involved in a relationship back home. A young woman meets less confusion or advances when she presents herself as married. In the rural areas I have worked in, girls often marry before they turn twenty, and an unmarried woman the age of a typical Western PhD student is rare. It is good to have a photo of a boyfriend or a husband or a man she could present as such. This was the case during my first field trips as a student, but still - as I was travelling with three men - I was perceived by the local interlocutors as a subordinate to one of these males: either as the

\footnotetext{
${ }^{1}$ I want to thank Bonnie Hewlett and Scott Calvert for their hard job to turn my strange English into a colloquial academic expression.
} 
student of the oldest man of the team - which I was - or as the wife of one of the members of the team.

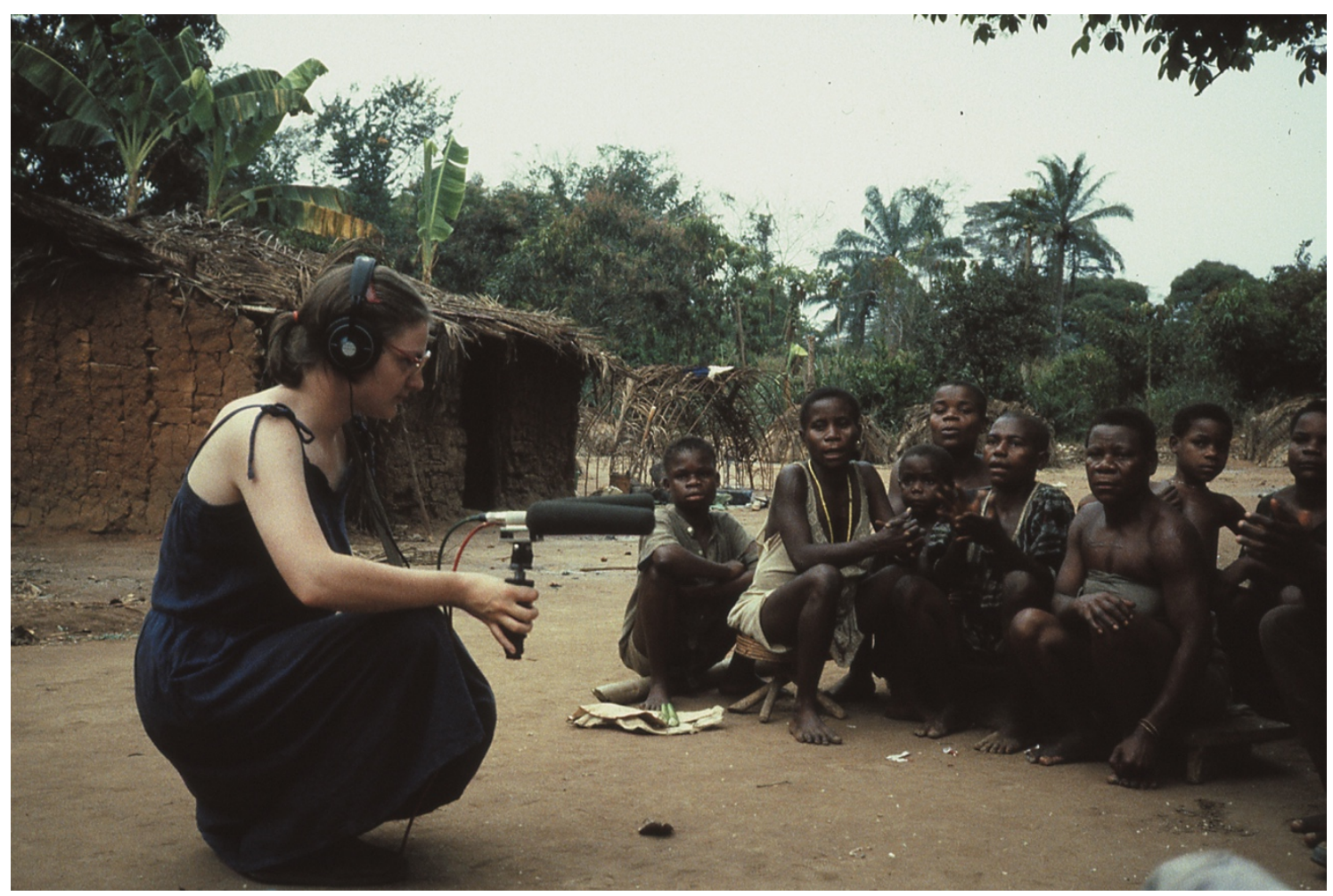

Fig. 1. Recording an Aka tale-song. Central African Republic, Mongoumba, 1989. (C) V. Dehoux.

One night, we were staying in a "case de passage", a small house dedicated to passing travelers in the town of Mongoumba, next to the residence of the Sous-préfet, the Deputy prefect of the district. He was absent when we had gone to introduce ourselves and came over later to greet us one night while we were having dinner. After talking a while with the professor, he looked at me and asked, "Is he [77] your husband?" - "No." Then he looked at the younger researcher: "He, then?" - "No, neither." With a sceptical look at the youngest man, he said, "So it is him, your husband?" - "No, Sir, none of them are my husband. I am not married." The astonished reaction appeared to be a deep failure to understand how I could not be married, I was twenty-nine, and how an unmarried woman could travel so far and work in such circumstances with three men, none of whom were her husband. From my actual point of view, I could add that he certainly imagined that I had sex with at least one of them

Travelling alone might be understood as a search for adventure. Whenever I travelled alone some men felt encouraged to make advances at me even knowing that I was married (see also Bombjaková, chapter $\mathrm{x}$ in this volume). The first time I conducted fieldwork alone I was thirty-four, a tenured researcher, married, and the mother of a one-year-old boy who had stayed in France with his father. Nevertheless, a man I hardly knew proposed to me by saying "Stay with me. You'll write to your husband that you won't come back again." When I answered that I had a child, he just said "That is even better." Looking back, this was a very harmless exchange during which a Central African man tried to hit on me. It was just a game. Still, at that time I was irritated. I have nothing against flirting, but this case didn't even really qualify as flirting to me. I had the impression that the man didn't really care about me or my 
loved ones. I thought knowing I was a mother should clearly establish a limit and be a reason for him to back off. How could he ask a mother to leave her child? Years later, during discussions about girls and women, both in the CAR and in Cameroon, I understood the value of a woman rises when "she has given", i.e. when she has shown she is able to have children. I always have problems with this expression, because it reflects the idea of reducing womanhood to reproduction, which is, from my Western point of view, totally unacceptable. Still, in these African countries, it is considered normal for even young women to have children. Many girls who go through the education system finish high school with a child, be they married or not.

\section{Advances}

Even if a woman is an academic, travelling without a man to whom she "belongs" raises questions and prompts certain men - from all walks of life - to make advances on her. In Cameroon, it is particularly difficult for an Occidental woman to stand the pervasive sexism expressed in words, looks, postures, and gestures.

\section{Police and other authorities}

It is especially difficult for me to deal with this attitude in situations where I am personally affected and when it occurs in very delicate interactions with administrative authorities I depend on. Every time our vehicle has to stop at a police checkpoint, I feel nervous. In several instances these stops lead to tense discussions [78] in which I am expected to account for any positive contributions, or lack thereof, my work as a French scholar would make towards the development of the country. Often, this is a hidden request for bribes, which, although not a demand towards women in particular, is made all the more difficult to deal with when the dimension of gender is added.

I once took my twenty-year-old daughter on a field trip to Cameroon. ${ }^{2}$ I was fifty-five. We travelled in a vehicle from the French research institute IRD. There are regular police checkpoints on the roads where you have to show your passport. Twice, young policemen took our passports, looked into the vehicle, saw me sitting in the front next to the driver and my daughter in the back. Then we heard them say while they were staring at her: "Is she your daughter? May I make her acquaintance?" Or, "How old is she? Is she married? Does she have a boyfriend?" They did not talk to her directly, but to me, her mother, as if it were I who decided who she should date.

A similar awkward situation occurred the first time I went to Cameroon in order to work with the Baka Pygmies. I was travelling with a younger woman who accompanied me as a photographer and videographer. I was thirty-nine, she was ten years younger. Again, we were travelling in an all-terrain vehicle with a driver from the IRD. On the way, we had to obtain a signature of the deputy prefect in order to move on to the Baka village. We met him in the morning of the Youth-and-Sports-Day, a national holiday on which pupils and bands parade all over the country. The deputy prefect told us to attend the parade. During the reception that followed, he stood in the middle of a room full of people sitting all along the walls when I went to him to ask for his signature. I wanted to arrive at our destination before nightfall. In response, he grabbed my butt and said, "You, you'll stay here tonight", using the French familiar form "tu". I was a tenured researcher and had shown him my official research permit, though. The only answer I was able to muster was "Oh, Monsieur le Sous-préfet, I

\footnotetext{
${ }^{2}$ I would like to thank Miriam Furniss-Yacoubi for her trust in me when allowing me to write about her difficult experience.
} 
don't think I will." But how to get my signature? I was really lucky to have met, earlier that day, another official who was a superior of the deputy prefect. He also attended the reception and so I asked him to give me the permission to leave. When I went back to the deputy in order to inform him that I was authorized to leave and that he had to sign my paper, he jumped up and shouted, "Who said that?" In my head, I was laughing with malicious joy for my victory when I indicated to him the person he had to obey. Two weeks later, he came to our Baka village and bothered my colleague asking her if she wanted to "taste a Cameroonian" offering her his sexual services against a trip back in an air-conditioned car. I had to intervene with authority as "head of the mission" in order to make him release my colleague's hand.

These situations are terrible, because men with authority take advantage of you. How to react? What to do if you want to follow your road and continue the work you set out to do? Is legitimate indignation a solution? I am not sure, but I can only offer the answer I have arrived at personally, which corresponds to my very intimate being-in-the-world and to what I have observed and what I have unconsciously integrated as means of communication and conflict resolution in such [79] contexts. My twenty-nine years of experience in Central Africa have taught me to keep a low profile in these situations: I want my passport back, I want the signature I need, and I want to hit the road in order to do my job. This is what I am there for. So, I put things into perspective and my pride in my pocket and try to make a gentle joke in order to lighten the atmosphere while showing that I shall certainly not give in.

I'll finish this section with a joyful anecdote: I was driving in the CAR when I did not recognize the stop sign for a police checkpoint. Thanks to the people accompanying me, I stopped at the very last moment. I was ready for a check though. At the end of the meticulous inspection of the vehicle and my research material, I had to go alone into the office and was asked to pay a horrendous fine. I didn't have enough cash in my purse, but I had money in a belt under my clothes. So, I asked the policemen for a place where I could take off some clothes in order to get the money. I sensed something like panic in the reaction of the men. What? The white lady wants to undress? They asked me how much I had in my purse and came to the conclusion that this should be the amount of the fine.

\section{Academia}

I must admit that I am still astonished - and in fact quite fed up - that although I am now over fifty, I am still the target of inappropriate words and gestures. If it were only men in the villages I work in or friends in the capital, it would be easier to handle. But this happens in academia, with colleagues, with whom I would like to work in the framework of potential institutional collaborations.

I was at a conference with African colleagues. At such events, everybody takes photos with everybody, mostly putting an arm around each other's shoulders or waist. I was standing next to a colleague whose academic activities I respect a lot. And suddenly I feel his fingers rub and pinch my sides, several times. I was free enough to tell him to stop, but he started again at other occasions, kneading my fingers every time we met or shook hands.

Such a situation is obviously not special to Africa and would not be worth mentioning here if there were not an underlying issue. A scholar needs a research permit to conduct fieldwork. This permit is determined by a partnership with local scholars. It is yet another instance of this very common situation experienced by millions of women in the world in which we must weigh our dignity against our professional interests. A riposte, no matter how well-deserved, can risk compromising institutional support. Male colleagues also have problems with potential research partners, but they are mainly concerned with various forms 
of financial or material requests that - needless to say - a woman also may encounter in addition to sexual harassment.

Lack of respect for women and their bodies may also be expressed verbally. The following, very dense, example addresses not only this issue, but also raises the question of whether, in a professional world dominated by men, it is necessary to behave like a man in order to be respected.

[80] I was invited to give a talk at the university. I was introduced to the audience that was composed of colleagues and students with these words: "This is Susanne. She is a man. And she lost weight since the last time I met her." I was choking with indignation: did I hear right? When I was given the floor, I politely thanked the professor and then gave the only answer I found in that situation: "But professor, would you have introduced me in the same way if I had been a man?" And then I started my talk with my full academic pedigree - two Masters in Music and Acoustical Phonetics, a PhD in Ethnomusicology and an HDR ${ }^{3}$ in Ethnology - in order to try to restore some semblance of authority that I was entitled to claim.

Two issues, authority and gender, merge in this example. As a senior researcher, my status is equivalent to a professor's and, in Cameroon, this is an enviable social status that affords real academic power. ${ }^{4}$ In this academic hierarchy, an individual's title informs others how he/she should be treated, the level of deference and respect that individual ought to be accorded, regardless of his/her actual competencies. There is therefore an obligation to address a person of high status not only with his or her personal name, but also with the appropriate title. This is an important rule to learn for a foreigner. Me? I was simply introduced as "Susanne". An explanation might be that for me the quality of a work is more important than the status of the person who accomplishes it. I do not behave as if my academic status made me more valuable than any other person. I am quite conscious that, in this domain, I clearly don't act like someone of my position is expected to in Cameroon. I suppose this might be interpreted as de-valuing myself. The fact that I am a woman also bears on my status outside academia. It often happens in meetings attended by "Mister Congressman", "Father", "Mayor", and "Majesty", I am "Susanne". It is as if familiarity and simplicity were incompatible with respect.

But, the fact that this colleague had completely ignored my title was, for me, a lesser offence. I was put off by the mention of my weight. I perceived this remark as an intrusion into my personal and intimate space. I know that in Cameroon weight is an external sign of wealth. I was several times encouraged to eat a lot in order to put on weight so that my husband would be happy and satisfied that I was well fed by the people I work with in the field. The expression "an administrative belly" refers to a man whose high social status is reflected in his waistline. I've never heard this expression applied to women though. I had lost weight. Had I therefore lost my status? I must admit that I have no answer to this question and still do not know what was meant by that statement.

The third point of offence in this example was the comment that I was "a man". The expression angered me so deeply that I stuttered as I began my talk. What did that mean? Can a woman not achieve what I do? This seems exactly to be the opinion of my interlocutors.

\footnotetext{
${ }^{3}$ Habilitation à diriger des Recherches, a French diploma that is necessary to access the status of senior researcher or tenure track professors.

${ }^{4}$ Several times, I have heard female students make allusions to sexual harassment by their professors and the deal that goes with it, known colloquially as "NST", short for "notes sexuellement transmissibles" - sexually transmitted grades. This is a play on the abbreviation MST, which stands for "maladies sexuellement transmissibles" - sexually transmitted diseases.
} 
When I brought this point up after the talk, someone told me that he had perceived this as a compliment, because only a man could do what I was doing, going alone to remote parts of the country where even many people from the capital would never go. So, finally, I learned this was a kind of promotion, I was considered as being more than a woman, because I "had the balls" to go there ...

[81]

\section{Good morning, sister!}

Religion - i.e. Christian denominations of any imaginable stripe - is omnipresent in the areas I work in. A minority of people are Muslim, but most of them are linked in one way or another to a Christian church. Incidentally, during my first years of fieldwork, I was always dismayed to see several "churches" in the same small village, most of them mere huts with a sign posted in front. But that's a different story ...

Especially among the Pygmy populations, the Catholic missions still constitute one of the most reliable social program networks, running schools and infirmaries, dedicated in no small part to the Pygmy population. Thus, the Catholic clergy are quite present, particularly nuns, as it is the female clergy who carry out this important work. Although some of them are Africans, most of the sisters I saw were European women. Therefore, most of the white women in the 1990s and early twenty-first century in my research areas were Catholic missionaries. Peace Corps volunteers have also been in the region, and nowadays one can expect to meet more white women working for environmental or development programs. It took me some time, though, to realize the only white women who stay for long periods of time and who live in daily contact with the local population still are religious women. Thus, it is not astonishing, that to most people white women are immediately assumed to be, or at least associated with, holy sisters of the mission.

When I meet people on the road or in another village who do not know me, I often hear them say "Good morning, Sister!" Having been raised in a northern German protestant family, this has irritated me for a long time. And somehow, it still does. I am not Catholic! I am not religious! It is not only the fact that I am a white woman alone in the African countryside that gives the impression I must be a nun. It is also my hair and style of dress. Like me, sisters wear knee-length dresses or skirts, cover their shoulders, and wear sturdy sandals. Like me, they typically have short hair. I had a good laugh once when talking about this with a taxi driver in Yaoundé. He looked at me and said: "No, you can't be a nun. You don't wear socks with your sandals."

As the Christian references generally make me feel uncomfortable, I have a tendency to gently provoke people. As an answer to the appellation "sister", I now often respond: "No, it's Madam", or "No, I am not your sister" as a direct response to the French salutation "ma sœur" (my sister). I know this is a bit childish, but it is a way of dragging a grain of sand on to the train tracks in hopes of derailing the pervasive assumption that every white person must be a practicing Christian. By identifying myself as a non-believer with a Lutheran protestant background, I often evoke incomprehension: How could one possibly live without believing? Without going to church on Sundays? The astonishment is even greater when I reveal that my husband is of Muslim heritage. How can he accept that I do not convert? How can he accept that I make this journey alone, that I work alone among men?

[82] In the beginning, I tried to stay away from church representatives in order to make clear that I was not affiliated with them, as I was there for scientific reasons. In the last decade, though, I have learned to appreciate and make the best of the Catholic network, both for housing and in the search of competent musicians. I supervised the PhD of a Cameroonian 
Catholic priest (Essélé, 2016), did ethnographic fieldwork with him, and had to argue for his research with both his bishop and the members of his parish. I now enjoy discussions about the place of traditional music and rituals alongside Catholic practices and feel that I am generally understood and accepted for who I am and what I do.

\section{DOING A MAN'S JOB}

In recent years, I've always had sufficient financial support to travel more safely, with a vehicle and driver. I've also gotten older and have clearly graduated to the status of "mature woman" being currently called "Ma mère" - my mother (see also Le Bomin, chapter $\mathrm{x}$ in this volume). Consequently, being a woman carrying out her fieldwork without the company of male colleagues is no longer an issue.

\section{Working on both sides}

In order to conduct comparative ethnomusicological research, i.e. comparing the musical heritages of different ethnic groups, it is necessary to work in many localities. When arriving in a place, one is immediately directed towards the local authorities - public or traditional ones - who in general are men. So are most of the ritual authorities and practically all instrument players. Thus, when working on musical heritages, one mainly deals with men and therefore gets introduced into social systems of music making from a male point of view. It took me some time to become aware of this intrinsic bias, which - at the time I was learning the ropes as an ethnomusicologist - was not at all perceived in French ethnomusicological academia. In my experience, a female scholar is likely to collect more or less the same kind of information as would a male colleague. Access to ritual or other esoteric, confidential knowledge, is limited by passage through initiation rites rather than by gender per se. The limits extend gradually as you show your integrity over the years. Thus, a female scholar and a non-initiated male scholar have equal opportunity to learn about male rites and maledominated social institutions.

In other respects, female researchers have an advantage over their male counterparts, since they also have access to the female spaces within these societies that men do not. Being a mother has particular advantages, as having gone through the experiences of pregnancy, childbirth, and motherhood confers a certain status and allows for very personal exchanges among women. I was sometimes astonished at the parallels between Western daily life and that of the Pygmy communities, chiefly in the responsibilities of family and health care. In the Pygmy context, I often give various items in addition to money as a compensation for their work with me. One time, in 1994, I also brought condoms among other goods such as [83] knives, spear points, pots, tobacco leaves, sewing needles, etc. I started to give them to men, but the women said "No, give them to us, because otherwise our men would never put them on. You know how they are, don't you?" Several times, I had the impression school supplies, clothes, and sometimes even money was best used for the entire family when it was given to a woman, "You know the men drink all the money" was a phrase I often heard. But I must admit that I was never integrated enough into the families to be able to verify that statement. Establishing strong ties with women is valuable not only in that it opens up access to female domains of knowledge, but also because it provides an opportunity for their voices to be better heard.

Being the "head of the mission"

Being responsible for a group of people travelling together (minimally my driver and I, but sometimes also a student), manipulating technical equipment, and conducting scientific 
research are activities that, in the view of many people in Africa, position the white female researcher in a customarily male position. It is she who makes the decisions concerning not only the research agenda, but also the living conditions she accepts or not. There is no ethical or practical contradiction between on the one hand working to integrate oneself into the society and on the other making firm decisions about whether to accept or refuse living in some particular person's house, to eat what they offer her or not, or to follow them in their daily life. Such decisions should be conditioned by the object of her research, by the period of time she will stay in a place, and by her personal capacity for adaptation.

Aside from issues of gender, "white privilege" is another aspect of doing research in Africa and many other areas of the global south that should be acknowledged and discussed. It was in the CAR that I first encountered the phenomenon of white privilege, which has often lent undue authority to my words and actions, allowing me to open doors I would not otherwise be able to. It is a bit difficult to accept that, although I neither embrace nor endorse it, I nonetheless benefit from it. I am still astonished at how easy it often is to gain access to people, and to organize meetings and interviews. I had to learn to manage this situation and to find the right balance between demanding and following, knowing and learning.

\section{Being courageous}

As I hope to have shown in the story of "being a man", it takes courage to conduct fieldwork alone as a woman. I must say that I always felt safer alone than during my first field trips with a relatively large team. My experience is that once I am "adopted" in a village, the owners of the house I am living in, the neighbors, and the people I am working with keep a close watch on me and my affairs.

The technical equipment an ethnomusicologist needs, as well as the amount of good clothes and things for daily life may encourage the idea that this lady must [84] be rich. The very fact of being there is proof of a researcher's wealth, regardless of his/her relative wealth in their home culture. It is difficult to avoid solicitations, both financial and material, to which we must respond with tact and firmness. Sometimes this may bring us into more or less dangerous situations of negotiation.

An important Baka initiation ritual took place in a forest camp, a three-hour walk from the village. I had been invited by the ritual leader and had given my contribution to the ceremony: rice, tobacco, and some money. I was accompanied by a local non-Baka assistant. Members of the extended family arrived and were irritated by my presence. Arguments were sparked. I heard that they wanted me to pay a lot of money, like a Japanese film team that had been there a month earlier. I refused to do so, because I had contributed to the ceremony according to the demands of the leader. But the quarrels continued and there was a real risk of a discord between the family members. I knew that my guide had his fields and a small hut at a walking-distance of twenty minutes. So, at three in the morning, I decided to leave in order not to jeopardize the success of the ceremony. We got up, took our affairs and walked away, directly into the forest. After five minutes, a young man came running behind us and asked us to come back. The ceremony continued, the spirit danced, and a Baka man came to inform me that the spirit would ask me to give some more money. That's what the spirit did and I agreed to add the small amount of money he demanded. 


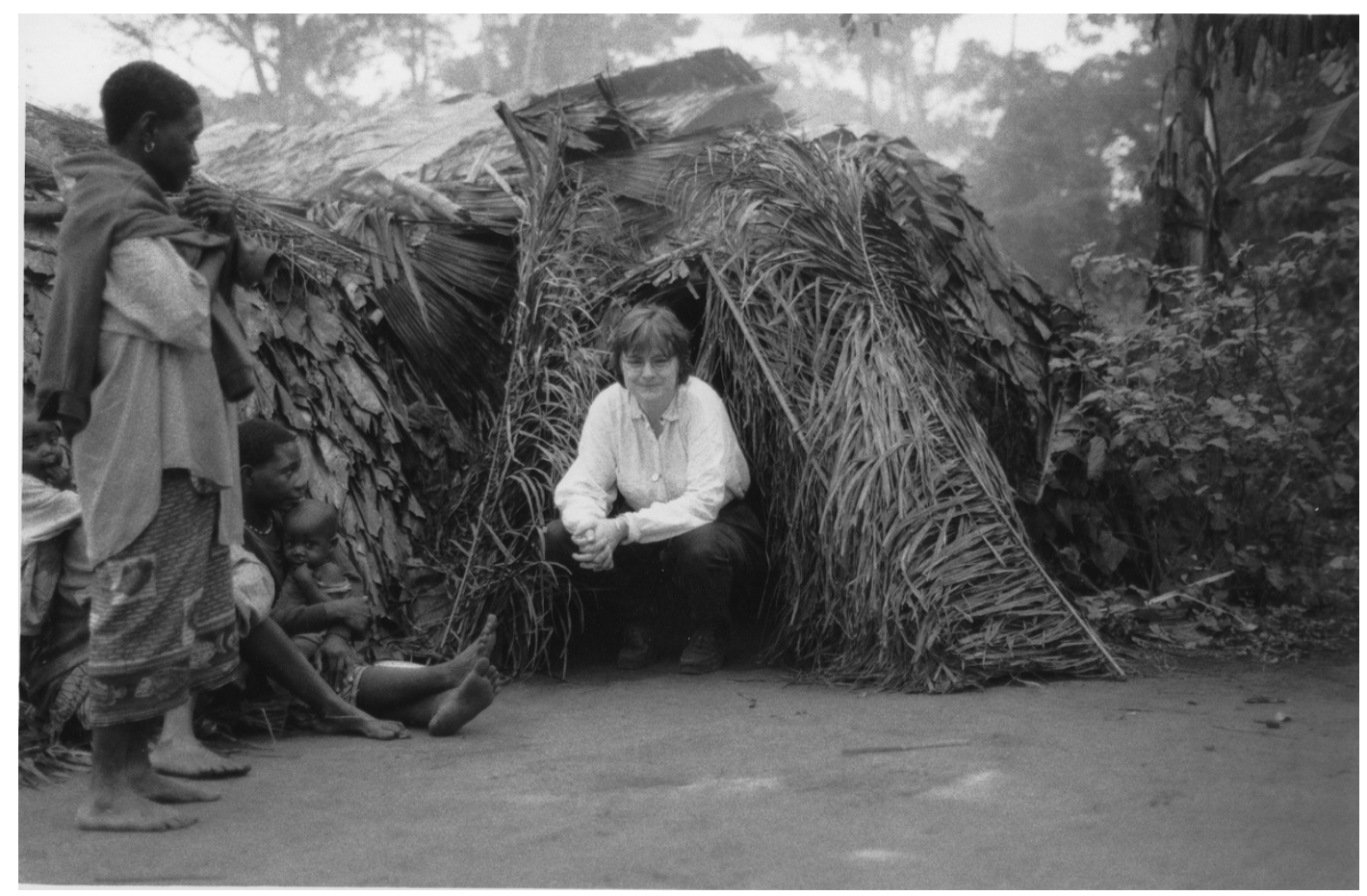

Fig. 2. First glimpse out of the hut in the morning of the second day of a circumcision ritual among the Baka. Cameroon, Ndjelo, 1999. (C) C. Lussiaa-Berdou.

This situation was not really dangerous, because no threat weighed on me. Other people had crossed the forest and the night to come to the ceremonial place, [85] I had myself walked the distance from my guide's hut, I was well-accompanied, and we had good flashlights. There was no reason to be afraid.

In another situation, I was perhaps more reckless, as my behavior could have led to a physical attack. I was attending a healing ritual of the Beti-Eton one evening, together with my student, who was also a priest in the nearby town. That day, we had negotiated our access to this event; although I was not the person who had ordered the ceremony, I had to pay quite a lot of money. The ceremony started, everybody drank a lot of alcohol, and the healer walked on embers. After some time, there was a discussion about the presence of the priest, and suddenly the music stopped again: the white lady would have to pay more if the ceremony was to go on. It was out of the question for me. There was a sick person, the ceremony should take place regardless of my presence. So, again, I just walked away, alone this time, in the middle of the road, going back to the house I stayed in. Again, they asked me to come back. But after a while, the dancer took a machete and whirled right in front of my face, staring at me with glassy eyes. He was clearly provoking me. What to do? Should I show the fear I felt? I did not want to give in, and instead started a power-struggle, standing there, upright, fixing my gaze on him. After a short moment, a man stepped in between us and positioned himself in front of me. The tension fell and the ceremony went on for a while longer, but without enthusiasm. The next day, the patient was dead.

My behavior is certainly not a model. Actually, I must admit that I acted rather without thinking, as an accident could easily have happened. I should have stepped back immediately. The dancer was not in a normal state after having drunk a lot of alcohol and probably taken drugs. While in the situation, I reasoned the man would not dare attack a white lady in the presence of a priest. 


\section{Doing analytical ethnomusicology}

I am an ethnomusicologist. I collect data through observation, taking written notes, taking images with photo and video cameras, as well as making sound recordings with professionalgrade equipment. I record music in its context, when people play in the evening, when there is a ritual ceremony, or when women sing in the kitchen. But I also make analytical recordings out of context. The work of an ethnomusicologist is unusual for people in Central African villages. Musicology - as much as ethnomusicology or anthropology - is a Western science. The questions an ethnomusicologist asks would not often occur to an African musician. Moreover, for African musicians the "grammar" of music is implicit, i.e. there is no formalized language to describe it. Therefore, it is necessary to adapt the Western musicological discourse and method of investigation in order to make a musical analysis in collaboration with African traditional musicians possible.

When recording polyphonic music or complex rhythms, my colleagues and I typically record each singer or percussionist individually, one by one (Arom, 1991). This technique allows us to transcribe the music and to describe its characteristic features - essential for accurate music analysis. As music is normally only [86] played in context and not taught in any formal or analytical way, this recording technique creates unfamiliar situations for the musicians. Therefore, the ethnomusicologist has to be able to establish trust and to lead the musicians with a certain authority through the recording sessions. Directing a recording session is a delicate exercise. One has to conduct - not unlike an orchestra conductor - the entrances and exits of each group of musicians, indicating to them when to vary their play and when to stick to the very minimal pattern of their part.

Wherever I have worked, the instrument players have been men and the singers often a group of women. This is very common in Africa. Some of my female students have told me that, due in large part to their young age and student status, it was not easy for them to be firm towards older male musicians. Personally, I was lucky to have learned this method with men, my professor and his colleague, in real fieldwork situations, because it allowed me to observe and imitate their demeanors, attitudes, and tricks. Those experiences were inspirational for me and gave me confidence once I was on my own.

In all my fieldwork experiences, it is always the analytical recordings that provide the moments of utmost joy. During a recording, the communication with the musicians is mainly through eye contact. In analytical recordings, each hand holds a microphone, and it is better not to speak so as to avoid contaminating the recording. All we have are our head and eyes to indicate to the musician when to start or to stop. During a recording of all musicians playing and singing at once, we use our eyes to distinguish the individual parts and to ask whether the parts are being played as they should be. When the session is going well, the intensity of the gaze I share with the musician is pure delight. I have the sense of meeting him totally in the act of playing. I understand what he is doing, and he knows that I understand and appreciate it. Even if earlier there had been arguments or misunderstandings, in that very moment, there is only the music and the player's mastery and the joy of following him through his musical progression. At times I feel intense satisfaction when he reveals each note as I expect him to, and then at others when, on the contrary, he innovates a musical surprise. It is the same with the singers. I initially hold them back from exploring any variations, signaling with my gaze that this dull procedure is necessary for the poor European lady to catch the basic structure of their part. Then, when I'm sure I've got it, I give the sign to let leave to all their art - this is the very moment where I am not a stranger anymore or a scholar, where the fact that I don't speak their language no longer plays a role, but where two musicians are just 
having fun together. I have so many overwhelming memories of this kind that still give me chills. This is why I accept all inconveniences and lack of comfort in the field. This is why I do my job.

And what is even more thrilling, is that many musicians consider this completely unusual exercise a positive experience. I worked on the Aka song repertoire that is accompanied by a harp-zither. This instrument has three strings on each side of a central bridge, each section being plucked by one hand. I made six recordings for each song: the singers and the instrument together, each of the three song parts, and, then, the right- and left-hand parts of the instrument separately. [87] There were children making a lot of noise. I was disturbed by the fuss and stopped the recording, saying to the player, "Ndolé, please send the children away, they make too much fuss." But Ndolé said to me, "No, Susanne, they have to stay. We normally never do what we are doing here. They have to learn."

This experience is one of my most important ones in terms of recognition of my work by the musicians themselves. Although the ethnomusicological approach is Western, although certain colleagues might perceive the separate recording of parts as a deconstruction, and although these recordings take place out of context, they nonetheless capture and illuminate the deep implicit structure of the musical material the musicians play with. As such, the situations I cause give the musicians the opportunity to make explicit through playing rather than through words - the foundational principles of their music. Thus, these recordings open up valuable possibilities for the transmission of ancestral knowledge, giving all those present opportunities to learn and to strengthen their musical skills.

\section{Having experience}

The fact that I have gained experience with African traditional music makes it possible for me to be more efficient during my work with the musicians and to establish a basis of collaboration based on mutual expertise. Working with Pygmy cultures, I have several times observed astonishment when the musicians realized I had not come only "to see the Pygmies dance", as this is most often the case with white people, but also with other people from the urban centers.

An anthropologist had published an article on the creation of spirit rituals among the Baka (Tsuru, 1998). His article contained a map with the villages he worked in. As the musical aspect had not been treated, I wanted to investigate how ritual creation works in the realm of rhythm and polyphony. I went to one village where the recent creation of a certain ritual had been identified and asked the people if they would play and sing for me another day. When I came back on the set day, there were two young drummers and some singers, just enough to show how the music works. They started playing and I saw that the two drummers basically played the same rhythm. I asked, "Is what they play correct?" - "Yes, it is correct." "Hmm, I had the impression they played the same thing. Could you play again, please?" They played again in the same way and I pointed out what I perceived as being the same thing "Yes, you are right, it is the same thing" "Would one drum be enough to play this rhythm correctly or do you really need two drums?" - "We need two drums." "So, I think that what they played is not correct, because in my experience there should be two different rhythms if there are two drums." Suddenly, an older man came from behind, pushing one of the youngsters aside with his elbow and said "I'll show you." He and the other drummer then played the complete version with the two different rhythms. It was not an hour since I had met these musicians. We hardly knew anything about each other. And still, I knew enough to make them understand that I could evaluate what they were playing. My experience came from the music I had already studied in other parts [88] of the Baka area. This is the kind of 
authority I have no difficulty embracing; on the contrary, it makes me happy because my authority in such instances does not derive from simply being white or a professor, but from a culturally recognized musical competency that permits me to get closer to the musicians I work with.

I experienced a similar thing among the Bagyeli when discussing spirit dances with a traditional healer. "We Bagyeli don't have spirits", he said. I could not help laughing: "Don't tell me that! You know, I worked in the CAR among the Aka who have mokondi, dio, edzengi, I worked with the Baka in East Cameroon, they have jengi, mokondi, emboamboa, ebuma, etc. I really would be very astonished if it was true that you don't have spirits!" He looked at me for a very long time, his gaze gradually turning into a smile: "Why do you ask if you already know the answer?" And he then started to tell me more about the Bagyeli spirits.

Ethnographic enquiries are sometimes like betting. Your experience might help you predict answers or reactions, as was the case here, but sometimes you are wrong. It is crucial to be humble enough not to insist on what one knows if it finally turns out to be wrong or inadequate. The Baka have borrowed a ritual to accompany the boys' circumcision (Fürniss and Lussiaa-Berdou 2004). The rhythm is based on nine values on which they superimpose four regular handclaps. This is totally against my experience, according to which there should have been twelve values for four handclaps or only three handclaps for nine values. So, I said, "You have an arithmetic problem, it's impossible to divide nine by four." They laughed and said, "Well, that is your problem. For us, this is how it is." It took me years to accept the facts that: (a) it was really only my problem that these folks had somehow developed a time structure without a simple ratio between meter and rhythm, which was totally unheard of in African ethnomusicology, and, (b) this is really how the rhythm is played by the Baka. For years, I thought I had made some critical ethnographic mistake. It was only when I noticed that my recordings from 1999, 2000, 2002, and 2006 all showed exactly the same phenomenon that I could accept it and address the theoretical issues that went with it (Fürniss, 2008).

\section{WHAT LESSONS TO LEARN?}

It is obvious the first thing you learn when doing fieldwork is that you have to zigzag between value systems and that your own values are not necessarily those of the people you are with. In Central Africa, as a young woman, you may be perceived as inferior to men, but the older one gets the more balanced the relationships are. It is most important not to allow these things to get to you, to affect your interior sense of self. Ambiguities, remarks on gender relationships, flirting both subtle and aggressive - in many cases what many Western women would call [89] sexual harassment - are frequent in Cameroon. It therefore seems vital to me that any woman researching in the area creates for herself an armor in order not to jump up each time she hears sexist remarks or smacking. We are in the field in order to conduct our research. We stay for a while and then go back home again. We are not in that place to educate people, or act as women's rights activists. We are there to do our job as anthropologists. I am glad I have never experienced any real danger to my own or my companions' integrity. Nor have I ever observed violence against Cameroonian women. I don't know how I would have reacted if I had. Not dramatizing this kind of situation is a question of experience and should not be confused with passivity or staying quiet.

On the other hand, neither are we in the field to have an affair. As I mentioned, for rural Cameroonians the popular image of the Western woman - as if ever such an essentialized type existed - is constructed through magazines, Brazilian soap series on TV, 
and cheap, often quite erotic, videoclips. I've heard young men say on several occasions that white women are always ready for sex. This means that a female scholar has to behave without any ambiguity. *Do not sleep with someone* is one of the first pieces of advice I offer my students. Even flirtation is not an option when doing fieldwork. Yes, one may be flattered, but it is not recommended at all to start a relationship in the field. Even if such an opportunity might be tempting, a fieldworker - woman or man - should not take advantage of it. This would create misunderstandings and complicate the research situation considerably. Our behaviour should never be such that it can be interpreted as an invitation. This includes a certain dress code, which excludes wide necklines, visible G-strings, or bras. It is about not mixing up the registers: we'll go for vacations and adventure after we are back from fieldwork.

Another confusion which should not be made is to mix up authority with authoritarianism. It is sometimes necessary for success in research and the researcher's wellbeing to be firm and this might be difficult for female students. Even in Western societies women have a tendency to try to "be nice". The fear of being perceived as dominant in an interracial context can thus lead a young female researcher to accept situations she feels uneasy about or where she has the impression of losing her freedom of decision. She should be conscious, though, that she must not feel obligated to accept everything from the people with whom she works. Firmness is also necessary to meet the aims of her research. It is she who is responsible for not losing sight of her objective in order to obtain the data she needs for her research project. In the ethnomusicologist's case, conducting analytical recording sessions demands an attitude that allows the female researcher to direct male musicians. But being firm does not mean to disrespect people and they know this. It is the experience that will help her to find a middle-way between her way of proceeding and the paths on which the musicians would like to lead her.

Within this balanced space where each partner makes a step towards the other with respect, I found the possibility to express from time to time my own point of view. Being provocative about religion, insisting on a woman's liberty to choose whether to be married or not and to whom, to be a mother or not, is part of my [90] personal little battle. As much as I have to question my values, I sometimes ask my interlocutors to question theirs. Thus, the encounter between persons from very contrasting geo-cultural backgrounds gives each of them the opportunity to think about what she or he would take for granted if they had not met.

\section{QUESTIONS FOR REFLECTION}

1. If you are a practising religious person, are you ready to separate your personal faith and your anthropological research?

2. How will you react if someone asks you to give him your batteries, or shoes, or mosquito net because he needs them? How will you refuse to give what is vital to you?

3. Have you already thought about how to express your femininity without external signs like make-up, trendy dresses, or jewellery?

\section{REFERENCES}

Arom, S. (1991) African Polyphony and Polyrhythm: Musical Structure and Methodology. Cambridge, Cambridge University Press.

Essélé Essélé, K. (2016) Continuités et innovations sonores des cérémonies funéraires des Éton du Sud-Cameroun. PhD Thesis, University of Paris Ouest Nanterre. 
Fürniss, S. (2008) "The adoption of the circumcision ritual bèkà by the Baka-Pygmies in southeast Cameroon". African Music. 8(2), pp. 94-113.

Fürniss, S. and Lussiaa-Berdou, C. (2004) Beka. Rituel de circoncision chez les Baka occidentaux du Cameroun. Available from: www.vjf.cnrs.fr/lms/sf/accueil.htm.

Tsuru, D. (1998) "Diversity of ritual spirit performances among the Baka Pygmies in southeastern Cameroon". African Study Monographs. Suppl. 25, pp. 47-84. 